Author: B Venter

\title{
A SELECTION OF CONSTITUTIONAL PERSPECTIVES ON HUMAN KIDNEY SALES
}

\section{ISSN 1727-3781}

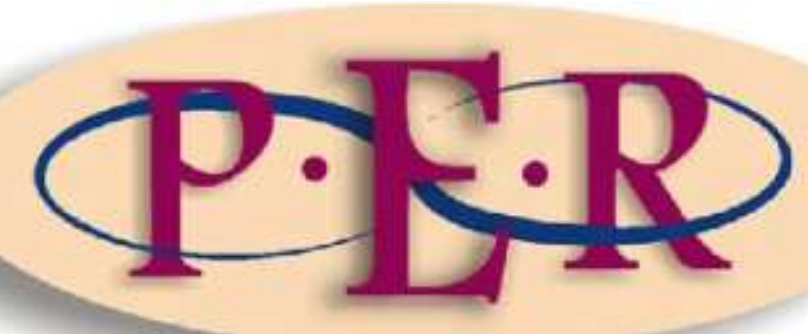

2013 VOLUME 16 No 1

http://dx.doi.org/10.4314/pelj.v16i1.11 


\section{A SELECTION OF CONSTITUTIONAL PERSPECTIVES ON HUMAN KIDNEY SALES}

\section{B Venter ${ }^{*}$}

\section{Introduction}

At the back of the abdominal cavity, just above the waist of the human body, two extremely vital organs are located. These organs are approximately 10 to $13 \mathrm{~cm}$ long and about 5 to $8 \mathrm{~cm}$ wide. They represent only $0,5 \%$ of the body's total weight, but together these two organs contain about $160 \mathrm{~km}$ of blood vessels that receive 20 to $25 \%$ of all the blood pumped by the heart. ${ }^{1}$ The body's total blood supply circulates through these organs about 12 times per day, and every hour they filter about 7,5 litres of blood. $^{2}$ These organs have the life-sustaining task of removing waste products and excess fluids from the body, and they will continue performing their task until they have lost 75 to $80 \%$ of their function. ${ }^{3}$ These organs are known as the human kidneys, and although most of us are born with two kidneys, life with only one kidney is possible. If a person's kidney does not perform its required function any more, he will have to undergo dialysis treatment until a kidney becomes available for organ transplantation.

Organ transplantation refers to a surgical operation where an organ is taken from one patient's body (also known as the "organ donor") and is placed into another patient's body (known as the "organ recipient"). The objective of organ transplantation is to restore a happy and useful life to a patient who was once doomed to a premature death due to a fatal disease of a vital organ. ${ }^{4}$

Bonnie Venter. LLB (NWU) LLM (UNISA). Lecturer, Department of Jurisprudence, University of South Africa. Email: venter.bonnie@gmail.com.

KHA 2008 http://bit.ly/ZzEJfQ.

KHA 2008 http://bit.ly/ZzEJfQ.

KHA 2008 http://bit.ly/ZzEJfQ.

Hakim Introduction to Organ Transplantation 2. 
Two main organ procurement systems are acknowledged internationally: an "optingin" system and an "opting-out" system. The opting-in system is a voluntary and altruistic system. According to this system a person has to give explicit informed consent before his death, confirming that he wants to donate his organs. ${ }^{5}$ Countries that follow the opting-in system include South Africa, ${ }^{6}$ Iran, the United Kingdom and the United States of America. ${ }^{7}$ In contrast with the opting-in procurement system is the opting-out system. According to this system everyone is a potential organ donor unless the person has registered before death that he does not want to be an organ donor. ${ }^{8}$ Countries that follow the opting-out system generally have a higher success rate. These countries include Singapore, Spain, Belgium and France. ${ }^{9}$ Neither of these organ procurement systems has been able to drastically improve the organ shortage of the countries that the systems are adopted in.

The purpose of this article is to establish if the sales of human kidneys could be regarded as constitutionally acceptable and thus as a solution to the current organ shortage. The South African Constitution ${ }^{10}$ is the supreme law of South Africa, and any legislation that is irreconcilable with it is invalid to the extent of the conflict. In this article a number of sections will be analysed, namely the rights to life, human dignity, self-determination, privacy and healthcare. These sections will be analysed to establish if it would be regarded as constitutionally acceptable for a person to be remunerated for the donation of one of his kidneys. One is already given the option to save a life by donating a kidney. One should also be allowed to choose to save a life and be remunerated for the deed.

Schicktanz, Wiesermann and Wöhlke Organ Transplantation 6.

If a person decides to become an organ donor in South Africa he is not placed on any list. A person can indicate his wish to become an organ donor to the Organ Donor Foundation. Once this is done, the donor will receive a card and two stickers for his identification document and driver's licence, to indicate that he is a donor (Organ Donor Foundation 2012 http://bit.ly/YqtVB8).

Hartwell 2010 http://bit.ly/149gfyc.

Schicktanz, Wiesermann and Wöhlke Organ Transplantation 7.

Hartwell 2010 http://bit.ly/149gfyc.

The Constitution of the Republic of South Africa, 1996 hereafter referred to as the Constitution. 


\section{$2 \quad$ Human rights and kidney transplants}

Imagine a world where human rights are seen as inconsequential. Everybody including the government would be free to do as they please and to treat other people as they like. In this world it would not be frowned upon if people were discriminated against on grounds of their race, religion or sexuality. Treating human beings with complete disdain and utter disregard for humanity would be commonplace. Incarceration in concentration camps, committing genocide, these horrific acts would be seen as justifiable based on prejudicial rhetoric. Furthermore in this fictional world it would not be regarded as unacceptable if non-consensual experiments were performed on human beings such as having their bones broken and their wounds infected until they had seizures and suffered cardiac arrest. ${ }^{11}$ If all of this sounds familiar it is because this world without human rights once existed before 1947. The horrific scene described above describes only some of the atrocities that took place during the Holocaust. During this era human rights weren't regarded as being as important as they are today and many atrocities were committed by the Germans against the Jewish people. The Holocaust led to the Nuremberg Trials, ${ }^{12}$ and these trials led to the Nuremberg Declaration that was promulgated in $1947 . .^{13}$ The Nuremberg Declaration has limited applicability as it deals specifically with human research and experimentation only; nonetheless it was the first step in the direction of the modern era of human rights. ${ }^{14}$ It was in 1948, one year later, however, that the most significant development in human rights took place - the adoption of the Universal Declaration of Human Rights by the United Nations. ${ }^{15}$ The Universal Declaration of Human Rights was adopted to set international standards of human rights, firstly to defend individuals against the abusive powers of organs of state and secondly to promote the opportunity for

\footnotetext{
$11 \quad$ Newman 2010 http://bit.ly/YHND7y.

12 The Nuremberg Trials were a series of military tribunals held by the victorious allies of World War II. The best known of these trials was the trial of the major war criminals where German officials were tried for crimes against peace, war crimes, and crimes against humanity (Schmidt Justice at Nuremberg 4).

McLean 2012 http://bit.ly/XrIpxs.

McLean 2012 http://bit.ly/XrIpxs.

McLean 2012 http://bit.ly/XrIpxs.
} 
individuals to develop through measures such education, healthcare and the provision of a safe living environment. ${ }^{16}$

It is clear that the relationship between human rights and medical ethics is undeniable. Human rights can be defined as the rights that we have as people from birth until death. They are comprehensively defined in various documents and codes. ${ }^{17}$ In South Africa they have been codified into international, regional and national human rights law. Firstly, human rights are protected by the International Bill of Rights that consists of the Universal Declaration of Human Rights, ${ }^{18}$ the International Covenant on Civil and Political Rights ${ }^{19}$ and the International Covenant on Economic, Social and Cultural Rights. ${ }^{20}$ As can be seen from these, human rights are broadly divided into categories. The three categories are civil and political rights, economic, social and cultural rights, and environmental rights. This article will focus mainly on the first two categories of human rights.

Civil and political rights, which are also known as 'first generation rights,' were introduced to protect people from oppression by the state. ${ }^{21}$ First generation rights ensure that everyone is entitled to participation in the political process and is free from interference by the government as long as his or her actions are not harmful to others. ${ }^{22}$ An example of a first generation right is the right not to be subjected to medical or scientific experimentation without consent.

Economic, social and cultural rights, which are also known as 'second generation rights,' were introduced because people need more than freedom from interference from the state to survive. For instance, they need access to economic and other

Dhai and McQuoid-Mason Bioethics 36.

Dhai and McQuoid-Mason Bioethics 36.

The Universal Declaration of Human Rights (1948), hereafter referred to as the UDHR.

The International Covenant on Civil and Political Rights (1966), hereafter referred to as the ICCPR.

20 The International Covenant on Economic, Social and Cultural Rights (1966), hereafter referred to as the ICESCR.

21 Dhai and McQuoid-Mason Bioethics 37.

22 Dhai and McQuoid-Mason Bioethics 37. 
resources like food and shelter to ensure an adequate standard of living. ${ }^{23}$ An example of a second generation right is the right of access to healthcare. Section 231 of the Constitution clearly states the importance of International agreements. The section reads that:

any international agreement becomes law in the Republic when it is enacted into law by national legislation; but a self-executing provision of an agreement that has been approved by Parliament is law in the Republic unless it is inconsistent with the Constitution or an Act of Parliament. ${ }^{24}$

At regional level South African human rights are protected by the African Charter of Human and People's Rights. ${ }^{25}$ In this article both the international and regional human rights instruments are mentioned briefly in relation to the specific human rights pertaining to kidney transplants.

The most important national document that protects South African human rights is the Constitution, or more specifically the Bill of Rights. The Constitution has a general impact on kidney transplants in three sections. In section 2 it is stipulated that the Constitution is the supreme law and that any law or conduct inconsistent with it is invalid, and the obligations imposed by it must be fulfilled. Secondly it is stated that the Bill of Rights must be respected, protected and fulfilled by the state. ${ }^{26}$ Thirdly in section $39(1)$ it is stipulated that when interpreting the Bill of Rights, a court, tribunal or forum must promote values such as human dignity, equality and freedom, and that International law must be considered and Foreign Law may be considered. In the Constitution there are also more specific fundamental human rights relating to kidney transplants such as the right to life, the right to human dignity, the right to self-determination, the right to privacy and the right of access to health-care services. These rights are discussed below. However, all of these fundamental human rights are not absolute and may be limited or restricted by section 36 of the Constitution.

Dhai and McQuoid-Mason Bioethics 37.

Section 231(4) of the Constitution.

The African Charter of Human and People's Rights (1981), hereafter referred to as the ACHPR.

Section 7(2) of the Constitution. 


\section{Section 36 of the Constitution: limitation of rights}

The human rights guaranteed by the Bill of Rights are not absolute. The general limitation section of the Constitution sets out specific criteria for the justification of restrictions of the rights in the Bill of Rights. ${ }^{27}$ Section 36 is referred to as a general limitation section because it applies to all of the rights in the Bill of Rights and limits all rights according to the same criteria. ${ }^{28}$ It should be borne in mind that a right cannot be lightly limited. A law may legitimately limit a right in the Bill of Rights if it is a law of general application to the extent that the limitation is reasonable and justifiable in an open and democratic society based on human dignity, equality and freedom. ${ }^{29}$ The law of general application can be summarised as follows: law for the purposes of this requirement is all forms of legislation, ${ }^{30}$ including common law ${ }^{31}$ and customary law. ${ }^{32}$ The general application requirement requires that the law must be sufficiently clear, accessible and precise that the persons who are affected by it can ascertain the extent of their rights and obligations. ${ }^{33}$ Consequently the law must apply equally to all. ${ }^{34}$ For the second part of the requirement that the limitation must be reasonable and justifiable in an open and democratic society, a number of relevant factors must be taken into account. These factors are: ${ }^{35}$

(a) the nature of the right;

(b) the importance of the purpose of the limitation;

(c) the nature and extent of the limitation;

(d) the relation between the limitation and its purpose; and

(e) less restrictive means to achieve the purpose.

Currie and De Waal Bill of Rights Handbook 163.

Currie and De Wall Bill of Rights Handbook 165.

Section 36(1) of the Constitution.

All forms of legislation include delegated and original legislation.

Common law includes both the private law and the public law rules.

Du Plessis v De Klerk 19963 SA 850 (CC). See also Currie and De Waal Bill of Rights Handbook 169.

Dawood v Minister of Home Affairs 20003 SA 936 (CC).

Currie and De Waal Bill of Rights Handbook 169.

Section 36(1)(a) to (e) of the Constitution. 
Thus it is clear that fundamental human rights in the Bill of Rights may be limited but only after a number of requirements have been fulfilled and if the limitation is for a legitimate reason. All human rights and their limitations in the Bill of Rights that are applicable to kidney donations will now be discussed.

\section{The right to life}

The right to life is regarded as the most fundamental of all human rights. ${ }^{36}$ The reason why this right is the most important is because it gives rise to all other rights. If a person is not alive he cannot be the bearer of other rights or exercise any of his rights, as observed by. O'Regan J in Makwanyane., ${ }^{37}$

The right to life is, in one sense, antecedent to all the other rights in the Constitution. Without life in the sense of existence, it would not be possible to exercise rights or to be the bearer of them.

The importance of the right to life has been reflected by the fact that the right is protected by all international and regional human rights instruments. ${ }^{38}$

\subsection{International and regional human rights instruments}

The right to life is firstly and most importantly protected by the UDHR, Article 3 of which clearly states that: "everyone has the right to life, liberty and security of person". The right to life contained in the UDHR has become so established in international law that it is described as having a jus cogens ${ }^{39}$ character, thus meaning that no derogation of this right is permitted. ${ }^{40}$ The right to life is also

\footnotetext{
Carsten and Pearmain Foundational Principles 27.

S v Makwanyane 19953 SA 391 (CC) para 326.

Rehman International Human Rights 68.

The notion of jus cogens has its origin in the Vienna Convention on the Law of Treaties (1969), which, in A 53 provides: "A treaty is void, if at the time of its conclusion, it conflicts with a peremptory norm of general international law. For the purposes of the present Convention, a peremptory norm of general international law is a norm accepted and recognized by the international community of states as a whole as a norm from which no derogation is permitted and which can be modified only by a subsequent norm of general internal law having the same character." (Dugard International Law 43). 
protected by article $6(1)$ of the ICCPR, which reads: "Every human being has the inherent right to life. This right shall be protected by law. No one shall be arbitrarily deprived of life". States such as South Africa that have ratified the ICCPR must at alltime take positive steps to effectively protect the right to life. ${ }^{41}$

At regional level the right to life is protected by article 4 of the ACHPR, which reads: "Human beings are inviolable. Every human being shall be entitled to respect for his life and the integrity of his person. No one may be arbitrarily deprived of this right." In most cases the African Commission has followed the jurisprudence of the United Nations Human Rights Committee regarding the right to life. ${ }^{42}$ However in some cases the African Commission has interpreted the right to life in a wider context. For instance, in the ground breaking case of Social and Economic Rights Action Centre $v$ Nigeria $^{43}$ the African Commission stated that the right to life implied a right to food as well. ${ }^{44}$ Even though the various international and regional human rights instruments may vary regarding the right to life, all of the instruments have in common the assertion that everyone has a right to life and that the state has an obligation to protect this right. In South Africa the right to life is ensconced in the Bill of Rights.

\subsection{The Constitution}

The year 1996 ushered in the dawn of a new era known as Constitutionalism, which changed the entire legal landscape in South Africa. Suddenly the doctrine of parliamentary sovereignty was replaced by the doctrine of constitutional supremacy. ${ }^{45}$ Constitutionalism now meant that the government could derive its

Joseph 2011 http://bit.ly/ZoHrl2.

Manby "Civil and Political Rights" 184.

Social and Economic Rights Action Center and the Center for Economic and Social Rights $v$ Nigeria Communication 155/96.

44 This case was about the environmental pollution of the Ogoni territory. The African Commission was of opinion that that the Nigerian Government was obliged to protect existing food sources from (amongst other things) environmental pollution. The Commission stated in this case that the destruction of land and farms was a violation of the right to life (Danwood 2002 Human Rights Brief 17).

45 Currie and De Waal Bill of Rights Handbook 2. 
power only from a written constitution and that its powers would be limited to those set out in the Constitution. ${ }^{46}$ The Constitution as described in Makwanyane:

provides a historic bridge between the past of a deeply divided society characterised by strife, conflict, untold suffering and injustice, and a future founded on the recognition of human rights, democracy and peaceful co-existence and development opportunities for all South Africans, irrespective of colour, race, class, belief or sex. ${ }^{47}$

The Constitution contains a Bill of Rights that protects the rights of each South African citizen. One of the most fundamental rights provided by the Constitution is found in section 11 and reads that everyone has the right to life which, along with the right to human dignity, must be valued above all other rights. ${ }^{48}$ The absoluteness of the right to life has also been upheld in a decision of the Hungarian Constitutional Court. ${ }^{49}$ In this decision it was said that other rights may be limited and may even be withdrawn and then granted again, but the right to life is absolute and must be preserved at all times. ${ }^{50}$ The South African Constitution differs from most other constitutions ${ }^{51}$ and also from the ICCPR due to the fact that it does not qualify the right to life. ${ }^{52}$ In the other constitutions the right to life is qualified due to the fact that the right to life may not be deprived arbitrarily. ${ }^{53}$ Chaskalson P remarks in the Makwanyane case that the right to life is given greater protection in the South African Constitution due to the fact that it is unqualified. ${ }^{54}$ According to section 7(2) of the Constitution the state has obligations to respect, protect, promote and fulfil the right to life. These obligations impose negative and positive duties on the state. The negative duty implies that the right to life must be protected to the extent that

\footnotetext{
Currie and De Waal Bill of Rights Handbook 8

S v Makwanyane 19953 SA 391 (CC) para 7.

S v Makwanyane 19953 SA 391 (CC) para 214.

Decision 23/1990 (X31) AB, as referred to by Currie and De Waal Bill of Rights Handbook 280 note 3.

$50 \quad S$ v Makwanyane 19953 SA 391 (CC) para 83-85. See also Currie and De Waal Bill of Rights Handbook 281.

51 It differs from the constitutions of other jurisdictions such as the United States, Canada, Hungary, and India (Currie and De Waal Bill of Rights Handbook 281).

52 Currie and De Waal Bill of Rights Handbook 281.

53 Currie and De Waal Bill of Rights Handbook 281.

54 S v Makwanyane 19953 SA 391 (CC) para 85: "Our Constitution does not contain the qualification found in section 54(1) of the Hungarian constitution, which prohibits only the arbitrary deprivation of life. To that extent, therefore, the right to life in section 9 of our Constitution is given greater protection than it is by the Hungarian Constitution".
} 
no one else can take it away. ${ }^{55}$ For instance one's right to life cannot be taken away by imposing the death penalty and one also has a right to defend one's life by means of self-defence. The positive duty obliges the state to protect the lives of its citizens. The question can be asked, though, if the state's duty to protect and promote life could be extended to include the prolonging of an end-stage renalfailure patient's life, where it is within the state's capabilities to do so.

\subsection{The right to life and kidney transplants}

In all the international and regional human rights instruments that were mentioned above it is obvious that everyone has a right to life and that this right may not be deprived arbitrarily. The South African Constitution even contains an unqualified right to life, thus it is not limited in anyway except by section 36 of the Constitution. Yet, none of these human rights instruments discusses what exactly the right to life entails. In South Africa the right to life was intentionally left unqualified and the Constitutional Court was given the authority to develop the notion, which is exactly what the court did in the Makwanyane case. Although this case focuses mainly on the invalidation of the death sentence, a number of important remarks were made regarding the right to life. In this article I should like to focus on how the right to life can be interpreted in such manner that the scope is extended to include the prolonging of an end-stage renal-failure patient's life by means of a kidney transplant.

Thus far it is evident that the right to life definitely entails a physical existence. Nonetheless what is the use of a right to life as a physical being if it is not a life worth living? In Makwanyane O'Regan J commented that: ${ }^{56}$

But the right to life was included in the Constitution not simply to enshrine the right to existence. It is not life as mere organic matter that the Constitution cherishes, but the right to human life: the right to live as a human being to be part of a broader community, to share in the experience of humanity. This concept of human life is at the centre of our constitutional values. The constitution seeks to establish

55 Cartens and Pearmain Foundational Principles 26.

56 S v Makwanyane 19953 SA 391 (CC) para 326. Own emphasis added. 
a society where the individual value of each member of the community is recognised and treasured. The right to life is central to such a society.

Sachs $\mathrm{J}$ enhances the idea of a life worth living by adding that the right to life could possibly impose a duty on the state to create conditions which will enable all persons to enjoy a life worth living. ${ }^{57}$ It could be argued that a patient with end-stage renal failure does not live a life worth living. Studies have shown that patients on dialysis have a noteworthy decrease in their quality of life. A patient on dialysis has to receive dialysis treatment three to four times a week, and each treatment takes three to four hours. ${ }^{58}$ Renal dialysis has a number of side effects that can be divided into physical and psychological effects.

Firstly the physical side effects are a decrease in energy levels and endurance, fatigue, headaches, pains, itchiness, loss of sight, nausea, cramps, infections and weight loss. ${ }^{59}$ All of these symptoms will seriously affect the performance of a person's simple daily activities. The psychological effects include depression, aggression, fear, mental anguish, sadness and stress. ${ }^{60}$ Consequently it is obvious that a patient on renal dialysis has to make long-term health and life style adjustments. In addition to the burden of the physical and psychological side effects, renal dialysis involves a great deal of expense. If the renal dialysis is supplied by the state, it costs the state more or less R200 000 per patient per annum. ${ }^{61}$ The patient in the private sector can look at a financial setback of more or less R40 000 to R60 000 per month. ${ }^{62}$ To make matters worse the majority of patients are not healthy enough to attend work each day, or their occupation does not allow them to attend during the hours when renal dialysis takes place, thus after they are retrenched they also suffer a loss of income. Above all it should be borne in mind that renal dialysis is only a life-prolonging treatment. It is not a cure for renal failure. ${ }^{63}$

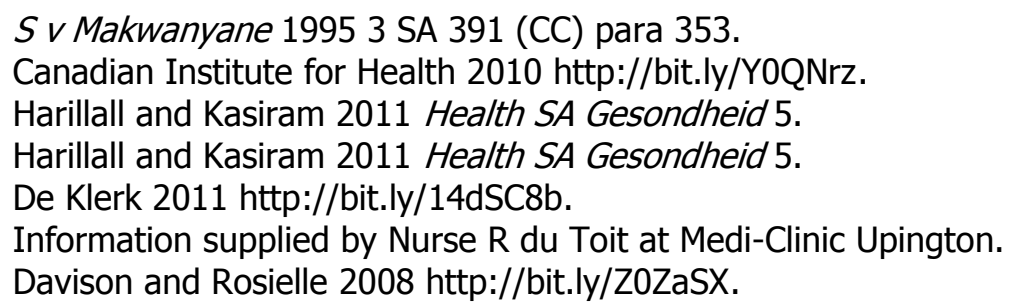


The ideal treatment for end-stage renal failure is a kidney transplant. ${ }^{64}$ Careful consideration of all the above mentioned facts may lead one to the conclusion that life on renal dialysis is not a life worth living. This is possibly the reason why so many patients decide to stop their dialysis treatment and rather go home to die. ${ }^{65}$ However a renal transplant has a number of benefits and clearly increases one's quality of life. ${ }^{66}$ In our Bill of Rights the state's positive obligations to make life liveable is mostly codified in our socio-economic rights such as the right of access to adequate housing ${ }^{67}$ and the right of access to health care, food, water and social security. ${ }^{68}$ This approach was confirmed in the Khosa $v$ Minister of Social Development ${ }^{69}$ case where it is said that the socio-economic rights in the Constitution are implicated with the right to life, human dignity, and equality. ${ }^{70}$ In these socio-economic right cases the availability of human and financial resources also has to be taken into account to determine whether the state complied with the constitutional standard of reasonableness. ${ }^{71}$

In Soobramoney $v$ Minister of Health (Kwazulu Natal) $)^{72}$ the court dealt with an application for life-saving medical treatment in the context of the socio-economic right to healthcare instead of the right to life. Soobramoney brought a constitutional application seeking an order for the hospital to provide him with access to dialysis treatment on the grounds that he needed emergency medical treatment. However the court dismissed his application because Soobramoney's health could not be seen as demanding emergency medical treatment as his condition was an "ongoing state of affairs". ${ }^{73}$ This case is discussed in more detail later in this article. Nonetheless one is left to wonder if the court's decision would not have been different if

Harillall and Kasiram 2011 Health SA Gesondheid 2.

National Kidney Foundation 2009 http://bit.ly/Y14Ptd.

Harillal and Kasiram 2011 Health SA Gesondheid 2.

Section 26 of the Constitution.

Section 27 of the Constitution.

Khosa v Minister of Social Development 20046 SA 505 (CC).

Currie and De Waal Bill of Rights Handbook 290.

Khosa v Minister of Social Development 20046 SA 505 (CC) para 44.

Soobramoney $v$ Minister of Health (KwaZulu Natal) 19981 SA 765 (CC). Hereafter referred to as the Soobramoney-case.

73 Soobramoney-case para 21. 
Soobramoney was a 25 -year-old healthy man with renal failure instead of a 41-yearold man who was extremely sick. ${ }^{74}$ One can also wonder if the decision would not have been different if the application had been brought on grounds of a right to life and a right to access to healthcare, not on a right to emergency treatment. ${ }^{75}$ Surely the results would have been different? In my opinion it could be argued that, as said above, there is an onus on the state to provide end-stage renal-failure patients with conditions that constitute an enjoyable human existence. Chaskalson P comments in Makwanyane that the right to life is one of the most important rights and the source of all other rights, and that these rights must be valued and the state must demonstrate this in everything that it does. ${ }^{76}$ Thus the state could supply these patients with an alternative that is within their available resources. These patients could be allowed to obtain a kidney for transplant purposes by buying it in a constitutionally acceptable manner. Then only will these patients be able to enjoy their human existence instead of having a right to a life that entails constant pain and suffering.

\section{The right to human dignity}

The right to human dignity entails the acknowledgement of the intrinsic worth of human beings. ${ }^{77}$ Human dignity is regarded as one of the supreme human rights. The reason for this is because the right to life and the right to human dignity are joined at the hip, as stated in Makwanyane by Ackermann $\mathrm{J}^{78}$

The right to life, thus understood, incorporates the right to dignity. So the rights to human dignity and life are entwined. The right to life is more than existence, it is a right to be treated as a human being with dignity: without dignity, human life is substantially diminished. Without life, there cannot be dignity.

74 As stated in the Soobramoney-case, Soobramoney was very ill. He was a diabetic who suffered from ischaemic heart disease and cerebro-vascular disease. He had suffered a stroke and was in the final stages of chronic renal failure (Soobramoney-case para 1).

75 In this case the Court suggested that the application of ss 27(1) and 27(2) of the Constitution were more appropriate to the facts of the case than ss 11 or $27(3)$ of the Constitution.

76 S v Makwanyane 19953 SA 391 (CC) para 144.

77 S v Makwanyane 19953 SA 391 (CC) para 328.

78 S v Makwanyane 19953 SA 391 (CC) para 327. 
Everyone has the right to be treated in a dignified and humane manner. ${ }^{79}$ The importance of human dignity is incorporated in various international human rights instruments as well as national constitutions. It is thus clear to see that human dignity is regarded as a universal duty and a universal responsibility. ${ }^{80}$

\subsection{International and regional human right instruments}

The main purpose of the right to human dignity is to try to correct the substantial violations of human dignity in the past and to prevent the reoccurrence of such violations in the future. ${ }^{81}$ The UDHR emphasises the importance of human dignity in its preamble, which states that the recognition of the inherent dignity of all members of the human family is the foundation of freedom, justice and peace in the world. The right to human dignity is also protected in article 1 of the UDHR, which reads: "all human beings are born free and equal in dignity and rights. They are endowed with reason and conscience and should act towards one another in a spirit of brotherhood." Additionally both the ICCPR and the ICESCR proclaim in their preambles that human rights are derived from the inherent dignity of the human person. Furthermore the Universal Declaration of Human Responsibilities ${ }^{82}$ explicitly asserts the importance of human dignity in articles 1 and 2 - which are categorised under the heading "Fundamental Principles for Humanity". Article 1 reads: "every person regardless of gender, ethnic origin, social status, political opinion, language, age, nationality or religion has a responsibility to treat all people in a humane way." Article 2 takes the responsibility even further and reads: "no person shall lend support to any form of inhumane behaviour, but all people have a responsibility to strive for dignity and the self-esteem of all others".

At regional level the right to human dignity is directly protected in article 5 of the ACHPR, which reads: "every individual shall have the right to the respect of the dignity in a human being and to the recognition of his legal status". Human dignity is

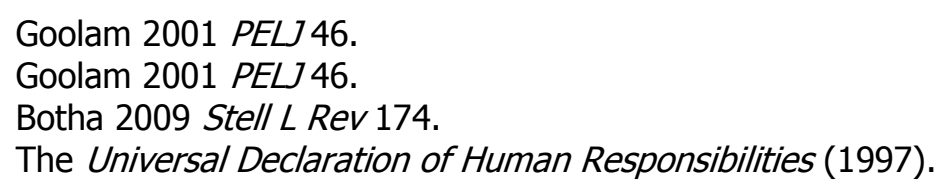


also protected in relation to the right to life in article 4 of the ACHPR, which reads: "every human being shall be entitled to respect for his life and the integrity of his person". In comparison with Western philosophies, African traditions lay great emphasis on the responsibilities of an individual as compared with his rights. ${ }^{83}$ In a Western context the main focus is on individual rights, whereas in an African context the focus is on community responsibility and loyalty. ${ }^{84} \mathrm{~A}$ perfect example of this African sense of community is ubuntu. In the system of ubuntu the life of another person is at least as valuable as one's own; thus respect for the dignity of every person is integral to it. ${ }^{85}$ Ubuntu is comprehensively explained by Mokgoro $\mathrm{J}$ in Makwanyane:

Generally, ubuntu translates as humaneness. In its most fundamental sense, it translates as personhood and morality. Metaphorically, it expresses itself in umuntu ngumuntu ngabantu, describing the significance of group solidarity on survival issues so central to the survival of communities. While it envelops the key values of group solidarity, compassion, respect, human dignity, conformity to basic norms and collective unity, in its fundamental sense it denotes humanity and morality. Its spirit emphasises respect for human dignity, marking a shift from confrontation to conciliation. ${ }^{86}$

It can easily be deduced that the right to human dignity plays a very important role in the South African Constitution since, as stated in section 1 of this contribution, South Africa is a sovereign democratic state founded on human dignity, freedom and equality.

\subsection{The Constitution}

In South Africa human dignity is regarded as the focal point of the Constitution, due to the country's horrendous past of racial segregation. As said in Makwanyane by O'Regan J:87

Goolam 2001 PEL 47.

Goolam 2001 PELJ 47. An ethic of community responsibility and loyalty can also be described as dharma.

85 S v Makwanyane 19953 SA 391 (CC) para 225.

$86 \quad S$ v Makwanyane 19953 SA 391 (CC) para 308.

$87 \quad S$ v Makwanyane 19953 SA 391 (CC) para 329. 
Respect for the dignity of all human beings is particularly important in South Africa. For apartheid was a denial of a common humanity. Black people were refused respect and dignity and thereby the dignity of all South Africans was diminished. The new constitution rejects this past and affirms the equal worth of all South Africans. Thus recognition and protection of human dignity is the touchstone of the new political order and is fundamental to the new constitution.

Amongst the trinity of human rights that South African society is based on, the right to human dignity is the most important. Human dignity is entrenched in sections $1,{ }^{88}$ $7,^{89} 36^{90}$ and $39^{91}$ of the Constitution. Section 10 of the Constitution explicitly proclaims that: "everyone has inherent dignity and the right to have their dignity respected and protected". As established by Chaskalson J in Carmichele v Minister of Safety and Security ${ }^{92}$ human dignity is a central value of the objective, normative value system which must guide the development of all areas of law. ${ }^{93}$ South Africa is regarded as possessing one of the world's most developed bodies of dignity jurisprudence. The only country that can compare with South Africa in this regard is Germany. Human dignity is not only a justifiable and enforceable right that must be respected and protected; it is also a value that is essential for the interpretation of all other fundamental rights and is of central significance to the limitation of other fundamental rights. ${ }^{94}$ In order to respect the right to inherent dignity everyone must be able to enjoy their civil and political liberties and also have access to the social and economic means essential to their development. ${ }^{95}$ It can thus be concluded that a person's dignity is denigrated if he lives in degrading living conditions and is deprived of his basic needs. ${ }^{96}$ Consequently the question can be raised whether a person in end-stage renal failure, who is dependent on renal dialysis, lives a life of human dignity or not.

88 Section 1 of the Constitution reads: "The republic of South Africa is one, sovereign, democratic state founded on the following values: (1) human dignity, the achievement of equality and the advancement of human rights and freedoms".

89 Section 7 of the Constitution reads: "This Bill of Rights is a cornerstone of democracy in South Africa. It enshrines the rights of all people in our country and affirms the democratic values of human dignity, equality and freedom".

Section 36 is the limitation clause that was discussed earlier.

Section 39 is the interpretation clause that was discussed earlier.

Carmichele v Minister of Safety and Security 20014 SA 398 (CC) para 56.

Currie and De Waal Bill of Rights Handbook 272.

Currie and De Waal Bill of Rights Handbook 275.

Liebenberg 2005 SAJHR 155.

Liebenberg 2005 SAJHR 156. 


\subsection{The right to human dignity and kidney transplants}

In section 10 the Constitution of South Africa specifically guarantees the right to human dignity. ${ }^{97}$ It is clear to see from the discussion above that the right to human dignity, like the right to life, is the fountain from which all other fundamental human rights flow. Both of these supreme rights have an absolute nature and must be preserved at all times. ${ }^{98}$ If either of these rights is taken away, all other rights cease. ${ }^{99}$ It should be borne in mind that human dignity demands a humane existence, as emphasised by Ackermann J in Makwanyane: ${ }^{100}$

The right to life, thus understood, incorporates the right to dignity. So the rights to human dignity and life are entwined. The right to life is more than existence, it is a right to be treated as a human being with dignity: without dignity, human life is substantially diminished. Without life, there cannot be dignity.

It can be deduced from this that life and human dignity are inseparable. Furthermore, health is an essential for both life and human dignity. It goes without saying that the capacity for the enjoyment of the right to life as well as human dignity is significantly diminished by poor health. ${ }^{101}$ According to the constitution of the World Health Organisation (WHO) dignity is a prerequisite of health. In this article the question is whether any human dignity exists in relation to renal dialysis, as well as to establish whether any human dignity is lost when a kidney donor receives a form of remuneration for the donation of his kidney. Lastly, a comparison is made between the mental anguish of a person on death row with that of a patient with end-stage renal failure.

Given that the right to human dignity entails that everyone has the right to be treated in a dignified and humane manner, the question can now be asked if a patient with end-stage renal failure, who is dependent on renal dialysis, leads a dignified and humane life.

\footnotetext{
S v Makwanyane 19953 SA 391 (CC) para 58.

S v Makwanyane 19953 SA 391 (CC) para 84.

S v Makwanyane 19953 SA 391 (CC) para 84.

S v Makwanyane 19953 SA 391 (CC) para 327.

Cartens and Pearmain Foundational Principles 29.
} 
It could be argued that if a patient has to attend his renal dialysis therapy three to four times a week for three to four hours a session ${ }^{102}$ he is not living a dignified and humane life. The fact that this patient will have to make significant adjustments to his life style instantly impairs his human dignity. Furthermore it could be argued that if a patient has to suffer all the various physical and psychological side-effects described above his human dignity will be impaired. It is evident that a person's human dignity is harmed when he has a decrease in energy levels, fatigue, pain, loss of sight, infection, nausea and cramps. The patient's human dignity is impaired even more by psychological effects such as depression, aggression, fear and mental anguish. ${ }^{103}$

It could also be argued that the dignity of neither the recipient of the kidney nor of the donor would be impaired in any way by means of kidney transplantation. It would be sensible to supply patients with viable donor kidneys and remove them from renal dialysis treatment. Kidney transplants would also be more cost effective than dialysis ${ }^{104}$ for society as a whole and would increase the recipient's human dignity and life expectancy. ${ }^{105}$ This argument can also be extended to the constitutional acceptability of the regulated sales of donor kidneys. One of the main arguments against a regulated market of kidney sales is that the selling of human kidneys constitutes a commodification of the body and consequently results in a decrease of human dignity. In this matter the question can be raised as to why sperm donors, egg donors, milk donors and surrogate mothers do not suffer a loss of dignity, but a kidney donor does? The words of Gill and Sade could be used to emphasise the position that human dignity is not decreased if a kidney donor receives remuneration: ${ }^{106}$

My kidney is not my humanity. In part, dignity is something that we convey by our behaviour and attitudes. If we establish a regulated system of sales, then it is our responsibility to create a culture of dignity for the paid donor. Many have suggested

\footnotetext{
102 Canadian Institute for Health 2010 http://bit.ly/YOQNrz.

103 Harillall and Kasiram 2011 Health SA Gesondheid 5.

104 The costs related to renal dialysis in comparison with a kidney transplant were discussed earlier in this article.

105 Clark 2006 http://bit.ly/WWupRe.

106 Gill and Sade 2002 Kennedy Inst Ethics J 20. See also Matas 2006 Clin J Am Soc Nephro 1131.
} 
that the term "paid donation" or "rewarded gifting" be used to confer dignity to the procedure.

The fact that a sum or value is placed on a person's kidney does not lead to a diminishing of a person's dignity. The court presently establishes the monetary value of the loss of or damage to a person's body parts by means of damage claims. This does not lead to a decrease in the value of a person's dignity. ${ }^{107}$ Slabbert states that monetary values are already attached to body parts: a diva is allowed to insure her voice and a tennis player can insure his arm. However, this does not diminish or impair their dignity. ${ }^{108}$

I would like to extend the scope of the right to human dignity to the right not to be treated or punished in a cruel, inhuman or degrading way. ${ }^{109}$ In Makwanyane it was proclaimed that one of the reasons for the abolition of the death penalty was because it was found to be a cruel, inhuman and degrading punishment. ${ }^{110}$ In this case it was stated that: ${ }^{111}$

Once sentenced, the prisoner waits on death row in the company of other prisoners under sentence of death, for the processes of their appeals and the procedures for clemency to be carried out. Throughout this period, those who remain on death row are uncertain of their fate, not knowing whether they will ultimately be reprieved or taken to the gallows.

The question that should be asked is how the situation of the prisoner on death row differs from that of the patient with end-stage renal failure. The patient who receives renal dialysis is basically on "death row." He receives his dialysis treatment along with other patients that are in the same position as he is. Like the prisoner on death row the patient is also uncertain of his fate. He does not know whether he will receive a donor kidney or eventually be left to die when renal dialysis is no longer a viable option. In Makwanyane reference is made to the mental anguish that a

Matas 2006 Clin J Am Soc Nephro 1131.

Slabbert 2010 PELJ 86.

Section 12(1)(e) of the Constitution.

S v Makwanyane 19953 SA 391 (CC) para 95.

S v Makwanyane 19953 SA 391 (CC) para 26. 
convicted prisoner suffers whilst awaiting his death sentence. ${ }^{112}$ Does a renal failure patient not suffer this exact same mental anguish whilst awaiting his "death sentence"? Furthermore the prisoner on death row does not have the burden of the financial implications that the renal dialysis patient has. It is regarded as unconstitutionally unacceptable to treat a convicted criminal in this manner but constitutionally acceptable in the case of an end-stage renal-failure patient.

Section 7(2) of the Constitution entails that the state must respect, protect, promote and fulfil the right to human dignity. From the above discussion it is evident that renal dialysis causes a decrease of a person's human dignity. It is also evident that a renal transplantation has the opposite effect and increases the person's dignity. In addition, it has been emphasised in this section that the sales of human kidneys would not lead to a decrease of human dignity. Thus the sales of human kidneys should be considered by the state as a viable and constitutionally acceptable manner to save thousands of lives whilst protecting a person's right to dignity.

\section{The right to self-determination}

The right to self-determination implies that a person has a right to make decisions regarding his own body. Self-determination is closely associated with the bioethical perspective of respect for autonomy that incorporates the doctrine of informed consent. The idea of control over one's own body can be illustrated by the following: ${ }^{113}$

I wish my life and decisions to depend on myself, not on external forces of whatever kind. I wish to be the instrument of my own, not of other men's, acts of will. I wish to be a subject, not an object; to be moved by reasons, by conscious purposes, which are my own, not by causes which affect me, as it were, from outside. I wish to be somebody, not nobody: a doer - deciding, not being decided for, self-directed and not acted upon by external nature or by other men as if I were a thing, or an animal or a slave ... I wish, above all, to be conscious of myself as a thinking, willing, active being, bearing responsibility for my choices and able to explain them by references to my own ideas and purposes.

112 S v Makwanyane 19953 SA 391 (CC) para 6.

113 Slabbert 2010 PEL 96. 
The idea of control of our own bodies is something that we as human beings practise every day through the various decisions that we are entitled to make. The importance of this right is clearly reflected in various international and regional human right instruments.

\subsection{International and regional human right instruments}

Like all other fundamental human rights the right to self-determination is firstly and most importantly protected by the UDHR. Article 3 stipulates that every individual has a right to life, liberty and security of person. Article 3 is comprised of three different rights: firstly the right to life, which includes the right to a humane existence (as discussed above), secondly the right to personal freedom, and lastly the right to security. The right to security entails the right to be protected against interference from the state as well as the protection of one's integrity. ${ }^{114}$ The fact that the right to the security of the person is listed along with the right to life could mean that this right should be regarded as being just as important as the right to life and human dignity. In international law the right to self-determination has been described as "one of the essential principles of contemporary international law" and it has been said that this right enjoys an erga omnes ${ }^{115}$ character. ${ }^{116}$ Additionally the right to self-determination is protected by the identical provisions of the ICCPR and the ICESCR. Article 1 of these human right instruments provides that: "all peoples have the right of self-determination. By virtue of that right they freely determine their political status and freely pursue their economic, social and cultural development". Self-determination is very broadly defined in International law and thus leads to every state deciding individually what the exact parameters of this right are. ${ }^{117}$

\footnotetext{
114 Rehof "Article 3" 89.

115 Erga omnes can be described as obligations which a state owes to the international community as a whole and in the enforcement of which all states have interest (Dugard International Law 43).

116 Dugard International Law 104.

117 Rehman International Bill of Rights 66.
} 
At regional level the right to determination is even less precise. The ACHPR protects this right in article 20, which reads: "All peoples shall have the right to existence. They shall have the unquestionable and inalienable right to self-determination. They shall freely determine that political status and shall pursue their economic and social development according to the policy they have freely chosen". The right to selfdetermination represents one of the most important roots of modern international human rights protection. ${ }^{118}$ Because this right is broadly defined, the African Commission has made numerous attempts to determine what exactly honouring the right to self-determination entails. ${ }^{119}$

\subsection{The Constitution}

The right to self-determination is guaranteed by the Constitution in section 12(2)(b), which reads: "Everyone has the right to bodily and psychological integrity, which includes the right to security and control over their body". As noted by Ackermann J in Ferreira $v$ Levin $^{120}$ the purpose of this section is to protect aspects of bodily selfdetermination. In Phillips $v$ De Klerk ${ }^{121}$ the right to control one's own body was recognized in so far as that right is not in conflict with the overriding social interest:

The mentally competent individual's right to control his own destiny in accordance with his own value system, his "selfbeskikkingsreg", must be rated even higher than his health and life.

The right to self-determination basically entails the right to be left alone, and in relation to one's body the right creates a sphere of individual inviolability. ${ }^{122}$ Section 12(2)(b) explicitly illustrates that this inviolability has two components, namely "security in" and "control over" one's body. The former entails the protection of bodily integrity against intrusions by the state and others; consequently the right to

118 Killander "African Human Rights Law" 401.

119 The African Commission has attempted to determine the exact parameters of the right to selfdetermination in various examples of case law such as Katangese People's Congress $v$ Zaire Communication 75/92.

120 Ferreira v Levin 19961 SA 984 (CC).

121 Phillips $v$ De Klerk 1983 TPD (unreported).

122 Currie and De Waal Bill of Rights Handbook 308. 
be left alone in the sense of being left unmolested by others. ${ }^{123}$ The latter entails the protection of what is described as bodily autonomy or self-determination against interference; consequently the right to be left alone in the sense of being allowed to live the life one chooses. ${ }^{124}$ In this section I will focus mainly on the latter right.

The fact that self-determination is an essential right is clearly illustrated by the capacity it protects - the capacity to express one's own character. ${ }^{125}$ By recognising an individual right of self-determination the Constitution makes self-creation possible. It allows each one of us to be responsible for shaping our lives according to our own distinctive personalities. Kriegler J observed in Ex Parte Minister of Safety and Security: In re $S v$ Walters ${ }^{126}$ that if the right to life, to human dignity or bodily integrity are compromised than the society to which we aspire becomes illusory. Kriegler J further emphasised the fact that any significant limitation to any of these rights would for its justification demand a very compelling countervailing public interest. ${ }^{127}$ But if a person is allowed to decide upon the fate of his own body, could the scope of such self-determination possibly be extended make it possible for a person to have the right be remunerated for a kidney donation?

\subsection{The right to self-determination and kidney transplants}

A person's typical day consists of making various decisions. Every waking moment is filled with decisions and choices such as what to wear, what to eat, and what his or her typical day will involve. In addition to these minor, mundane daily choices that one makes, one also makes major decisions that have an influence on one's life, such as what religion, lifestyle or career to follow. Obviously, then, everyone has the right to make decisions regarding control over their own bodies. This right is, after all, guaranteed in various international human right instruments and even explicitly in the Constitution. Yet, these same autonomous persons are not granted the opportunity to choose to be remunerated for a kidney donation?

Currie and De Waal Bill of Rights Handbook 309.

Currie and De Waal Bill of Rights Handbook 309.

SALC Assisted Decision-making 23.

Ex parte Minister of Safety and Security: In re S v Walters 20024 SA 613 (CC) para 28.

Ex parte Minister of Safety and Security: In re S v Walters 20024 SA 613 (CC) para 28. 
South Africans are more aware of the fact that they have a right to selfdetermination than they were 18 years ago. Since 1994 they have been allowed to become more and more autonomous by the day, even to the extent that since 1 February 1997 mothers are allowed to legally terminate their pregnancies. ${ }^{128}$ In the landmark case Christian Lawyers Association of South Africa v Minister of Health ${ }^{129}$ it was noted by Mojapelo $\mathrm{J}$ that if the state were to prohibit termination: ${ }^{130}$

... the state's interference would clearly constitute an impairment of women's right "to bodily and psychological integrity" and more particular their right "to make decisions concerning reproduction" and "to security in and control over their body".

Why is the termination of a pregnancy constitutionally acceptable yet a kidney donor is not granted the choice to be remunerated for the donation of his kidney? The Constitution clearly states that "everyone" has the right of control over their body, thus the kidney donor should be allowed to receive remuneration for his kidney if he wishes. At the very least, he or she should be given the choice of being remunerated. Presently a person only has the choice to donate a kidney altruistically. The pregnant mother is allowed to end the life of her unborn child because she firstly has the right to bodily and physically integrity and secondly the right to control over her body. As stated in the Christian Lawyers case ${ }^{131}$ "the fundamental right to self-determination itself lies at the very heart and base of the constitutional right to termination of pregnancy".

Consequently, on the grounds of section 12(2)(b) of the Constitution a kidney donor has a right of control over his body and thus has the right to do with his body as he pleases. If one is allowed to end a life due to the possession of one's fundamental right to self-determination than surely one should be allowed to save a life based on this exact same right. To make matters even worse, according to section 5(3) of the choice on termination of pregnancy act, any woman of any age is allowed to consent

\footnotetext{
128 The Choice on Termination of Pregnancy Act 92 of 1996.

129 Christian Lawyers Association of South Africa v Minister of Health 19984 SA 1113 (T).

130 Christian Lawyers Association of South Africa v Minister of Health 19984 SA 1113 (T). See also Carstens and Pearmain Foundational Principles 98.

131 Christian Lawyers Association of South Africa v Minister of Health 19984 SA 1113 (T). See also Carstens and Pearmain Foundational Principles 92.
} 
to an abortion. ${ }^{132}$ The implication of this section is that a minor as young as 12 years old is allowed to legally terminate her pregnancy without the consent of a parent. If a minor is allowed to make vital decisions regarding her body it could be argued that a competent adult kidney donor should be allowed to decide to donate a kidney and benefit financially in return.

Because of a person's strong right to self-determination a person even has the right to refuse medical treatment. ${ }^{133}$ In most cases the refusal of medical treatment results in death. It could be argued that if a patient is allowed to make decisions that could result in his death then a kidney donor should surely be allowed to make the decision to donate his kidney and receive remuneration for the donation. Donating a kidney does not result in death, as is the case with abortion or the refusal of medical treatment. It results in quite the opposite: it saves the life of another person.

Section 7(2) of the Constitution entails that the state must respect, protect, promote and fulfil the right to self-determination. From the above discussion it is clear that the right to self-determination has already been developed to a certain extent. It is regarded as constitutionally acceptable for women to terminate their pregnancies due to this right and for patients to refuse essential medical treatment. Both of these practices result in death - firstly the death of the unborn child and secondly the death of the patient. I am of the opinion that if a person is allowed to make such a decision on the grounds of the person's constitutional right to self-determination, then a kidney donor should be allowed to receive remuneration for his kidney donation. The kidney donor is also entitled to the right to make decisions regarding control of his body. It should be borne in mind that a person is already legally allowed to donate his kidney, it is the remuneration of a kidney donation that is regarded as illegal. The question however could be raised what difference would the

132 Section 5(3) of the Choice on Termination of Pregnancy Act 92 of 1996 reads: "In the case of a pregnant minor, a medical practitioner or registered midwife, as the case may be, shall advise such a minor to consult with her parents, guardian, family members or friends before the pregnancy is terminated: Provided that the termination of the pregnancy shall not be denied because such a minor chooses not to consult them" (Own emphasis added).

133 Section 6(d) of the National Health Act 61 of 2003 states that: "Every health care provider must inform a user of - (d) the user's right to refuse health services". 
added benefit of remuneration make to the kidney donor's right to selfdetermination? In my opinion it would make no negative difference. The donor chooses to sell his kidney. It is only a part of his body. After his kidney is removed he still has his whole body to have control over. If the remuneration of a kidney donor is regarded as constitutionally acceptable it will pose no disadvantage to the donor's right of self-determination. It would instead develop his right,- which would then include the right to be allowed to choose to receive remuneration or not. The donor would be allowed to make his own decisions regarding his body whilst prolonging the life of another person in need of a kidney transplant.

\section{$7 \quad$ The right to privacy}

The right to privacy can broadly be defined as the fundamental right of an individual to isolate his private life from the interference of the state or other persons. This right makes it possible for the individual to control what he wants to share with or withhold from others. Privacy is regarded as a very important aspect of a person's personality and thus a person has an interest in the protection of his privacy. ${ }^{134}$ In the last few decades the right to privacy has developed and become widely recognised in various human rights instruments.

\subsection{International and regional human right instruments}

The protection of territorial and communications privacy is explicitly guaranteed in the UDHR. Article 12 reads:

No one shall be subjected to arbitrary interference with his privacy, family, home or correspondence, nor to attacks upon his honour and reputation. Everyone has the right to the protection of the law against such interference or attacks.

The right to privacy is also further dealt with in article 17 of the ICCPR. The phrasing of this article is identical to that of the UDHR. Article 17 has been elaborated further by the Committee's General Comment and also by its case law under the Optional

134 Neethling et al Law of Personality 29. 
Protocol. ${ }^{135}$ In the General Comment on this Article the Committee noted that the obligations imposed by it require the state to adopt legislative and other measures to give effect to the prohibition against such interferences and attacks as well as to the protection of this right. ${ }^{136}$

The right to privacy is not explicitly guaranteed in the ACHPR but it is found in most domestic bills of rights such as the South African Bill of Rights.

\subsection{The Constitution}

In South Africa an individual's right to privacy is protected by both the common law and the Constitution. According to the common law every person has an independent personal right to privacy. In this section, however, I will focus only on a person's constitutional right to privacy.

Section 14 of the Constitution reads that "everyone has the right to privacy, which includes the right not to have their person or home or property searched, their possessions seized or the privacy of their communications infringed". The right to privacy has two parts: the first guarantees a general right to privacy and the second protects people against specific infringements of privacy such as searches, seizures and the infringement of communication. ${ }^{137}$ It should be noted that unlike the three fundamental human rights discussed earlier, the right to privacy is not absolute. It can be limited in accordance with section 36 (the limitation clause) of the Constitution. The purpose of this limitation is to enable the courts to find a balance between the public's right to know and the individual's right to privacy. ${ }^{138}$

The right to privacy aims to protect three categories of an individual's life. The first category protects a person against intrusions and interferences with his private

Rehman International Bill of Rights 78.

136 UN Human Rights Committee $1988 \mathrm{http}: / /$ bit.ly/ZfoHEn paras 1, 8. See also Rehman International Bill of Rights 78.

137 Currie and De Waal Bill of Rights Handbook 315.

138 Devenish Commentary 157. 
life. ${ }^{139}$ In respect of this right a person is entitled to be left alone. The purpose of this right is to establish that the state and other people have nothing to do with a person's intimate affairs. The second category protects a person's privacy against infringement of his autonomy and allows every individual to choose the kind of lifestyle that he wants to lead. ${ }^{140}$ The third category protects a person against the infringement of private information. ${ }^{141}$ This right is closely related to the right to human dignity, since the publication of false information that reflects negatively on a person can damage a person's dignity. ${ }^{142}$ In this section the focus is mainly on the third category - informational privacy. In the medical context the right to privacy is further protected by section 14 of the National Health $A c t .{ }^{143}$ Furthermore the Promotion of Access to Information Act ${ }^{144}$ stipulates that no person may disclose any information about a patient unless the patient gives his written consent, or a court order requires the disclosure, or the non-disclosure represents a serious threat to the public health. ${ }^{145}$ One could ask if the remuneration of kidney donors would constitute a breach of the donor's right to privacy.

\subsection{The right to privacy and kidney transplants}

Information pertaining to a person's health is regarded as highly confidential, and as stated above it is protect by the Constitution, the National Health Act and the Promotion of Access to Information Act. In Hyundai Motor Manufacturers ${ }^{146}$ it was noted that:

Privacy is a right which becomes more intense the closer it moves to the intimate personal sphere of the life of human beings, and less intense as it moves away from that core ...

Currie and De Waal Bill of Rights Handbook 324.

Jordaan South African Consumer's Information Privacy 25.

Currie and De Waal Bill of Rights Handbook 323.

Currie and De Waal Bill of Rights Handbook 323.

Section 14 National Health Act 61of 2003 reads: "All information concerning a user, including information relating to his or her health status, treatment or stay in a health establishment, is confidential."

144 The Promotion of Access to Information Act 2 of 2000.

145 Dhai and McQuoid-Mason Bioethics 88.

146 Investigating Directorate: Serious Economic Offences $v$ Hyundai Motor Distributors (Pty) Ltd: In re Hyundai Motor Distributors (Pty) Ltd v Smit 20011 SA 545 (CC). 
It could easily be said that a kidney transplant is part of one's intimate personal sphere of life. The right to privacy pertaining to a kidney transplant could easily be breached if a kidney donor's identity is revealed to the kidney recipient. In this section I would like to show that allowing a kidney donor to be remunerated for his donation would not infringe his right to privacy.

Presently, in South Africa the details of all cases of kidney donation are regarded as confidential, except of course in the case of living donors where transplants are done within the same family. ${ }^{147}$ The implication of this confidentiality is that the identity of the kidney donor is protected and is not revealed to the kidney recipient. The reason for this being so is that the kidney donor's right to privacy is regarded as stronger than the kidney recipient's right to information.

In the United States of America a case study was done regarding whether or not the donor's right to information would outweigh the recipient's right to privacy if the kidney recipient was HIV positive. ${ }^{148}$ In this case study it was concluded that the recipient's right to privacy was dominant, as a kidney donation is completely voluntary and the donor shouldn't base his choice on the transplant outcome. ${ }^{149} \mathrm{I}$ am of the opinion that if this case study were to be done in South Africa the results would be the same, mainly because the right to privacy is so strongly protected by the Constitution. I further feel that this case study emphasises the importance of the right to privacy. In South Africa especially the importance of the right to privacy is clearly illustrated by the fact that minors are allowed to obtain condoms, abortions and HIV tests without the knowledge of their parents. ${ }^{150}$

Given this context it is argued that by allowing a kidney donor to be remunerated for his donation would not infringe his privacy. In Singapore the remuneration of kidney donors has had no effect on the privacy of the kidney donors. According to the Minister of Health of Singapore the identity of the kidney donor is confidential 
information. ${ }^{151}$ The kidney donor's privacy could be infringed only if his identity is revealed to the recipient. If remuneration is allowed it would not change the current position. The mere fact that the kidney donor would receive an added benefit does not force him to reveal his identity.

\section{The right to health care}

In all parts of the world a person's health is vital to all other aspects of his life, such as his personal and social development. A person needs to be healthy to live his life to the fullest. Without health a person cannot do his work, care for his family or enjoy his life. Enjoyment of the right to life is interlinked with and crucial to the realisation of many other fundamental human rights such as the right to life, to dignity, to self-determination and to privacy.

The right to health did not officially emerge from an international human rights instrument as did other fundamental rights but rather from an international health authority. ${ }^{152}$ In the preamble to the constitution of the World Health Organisation, ${ }^{153}$ which was written in 1946, it was proclaimed that: "the enjoyment of the highest attainable standard of living is one of the fundamental rights of every human being". According to the WHO, health can be defined as: "a state of complete physical, mental and social well-being and not merely the absence of disease or infirmity". Unfortunately, for the majority of the world and especially for South Africa, reality falls far short of the WHO standard.

The right to health is further protected by international and regional human rights instruments.

\footnotetext{
151 Minister of Health 2008 http://bit.ly/YqsHG5.

152 Ngwena and Cook "Rights Concerning Health" 108.

153 Hereafter referred to as the WHO.
} 


\subsection{International and regional human rights instruments}

The right to health is protected in the first place by Article 25 of the UDHR, which reads: "Everyone has the right to a standard of living adequate for the health and well-being of himself and of his family including food, clothing, housing and medical care ...". ${ }^{154}$ The UDHR aims to promote "a common standard of achievement for all peoples and all nations". ${ }^{155}$ Unfortunately the UDHR has one missing component with regard to the right to health. It does not impose an obligation on the state to take positive measures toward the realisation of this right. This lacuna was addressed and corrected by the ICESCR. Article 12(1) of the ICESCR reads: "The State Parties to the present Covenant recognize the right of everyone to the enjoyment of the highest attainable standard of physical and mental health". The steps required for the realisation of these rights are stipulated in Article 12(2) of the ICESCR. ${ }^{156}$ The obligation to take steps toward the realisation of this right is mandatory, but every state has a margin of discretion in the choice of appropriate means for satisfying the right to health. ${ }^{157}$ The Committee on the ICESCR has established that there must be a maximum deployment of available resources towards the realisation of the right to health. ${ }^{158}$ If a state cannot meet the full realisation of a right due to its lack of resources, it must at least endeavour to meet a certain minimum-level content of the right. ${ }^{159}$ Consequently it can be deduced that the state must demonstrate that it has deployed its available resources to the maximum extent. It should be borne in mind that the Committee also emphasised

154 The Article further states that everyone has the right to security in the event of unemployment, sickness, disability, widowhood, old age or other circumstances beyond his control resulting in the lack of a livelihood. The author regards only the first part of this definition as important to the discussion of the right to healthcare.

155 Ngwena and Cook "Rights Concerning Health" 111.

156 Article 12(2) of the ICESCR reads: "The steps to be taken by the State Parties to the present Covenant to achieve the full realisation of this right shall include those necessary for: (a) the provision for the reduction of the stillbirth-rate and of infant mortality and for the healthy development of the child; (b) the improvement of all aspects of environmental and industrial hygiene; (c) the prevention, treatment and control of epidemic, endemic, occupational and other diseases; (d) the creation of conditions which would assure to all medical service and medical attention in the event of sickness."

157 Ngwena and Cook "Rights Concerning Health" 113.

158 Ngwena and Cook "Rights Concerning Health" 114.

159 Ngwena and Cook "Rights Concerning Health" 114. 
that the availability and accessibility of health care for all individuals is a provision that should be sensitive to medical ethics and distinct cultures. ${ }^{160}$

As a result of the influence of international human right instruments the right to health is also protected on regional level by the ACHPR. Article 16(1) reads "Every individual shall have the right to enjoy the best attainable state of physical and mental health". Article 16(2) provides for the realisation of the right by stating that: "State parties to the present Charter shall take necessary measures to protect the health of their people and to ensure that they receive medical attention when they are sick". It is clear that the right to health is an important right although compliance with its obligation remains rather problematic.

The right to health is explicitly recognised as a fundamental right in the Constitution.

\subsection{The Constitution}

During the era of apartheid ${ }^{161}$ South Africa perpetrated a number of violations against the human right to health. The racial segregation of white and black people affected people's health in a number of ways. The health of the disadvantaged was affected due to the poor social conditions in which they lived, which caused ill health, the segregation of state health services, and the state's unequal spending on health services. ${ }^{162}$ Since 1994 health in South Africa has been recognised as a fundamental human right.

The right to health is guaranteed explicitly by the Constitution in section 27(1)(a), which reads: "everyone has the right to have access to health care services, including reproductive health care." ${ }^{163}$ It should be emphasised that the Constitution does not guarantee a right to health, but only the right of access to health care

\footnotetext{
160 UN CESCR 2000 http://bit.ly/102nBOG para 12. See also Rehman International Bill of Rights 119. 161 From 1948 to 1994.

162 Heywood "Background to Health Law" 11.

163 Section 27(1) of the Constitution further states that everyone has the right to have access to sufficient food, water and social security. These rights, however, will not be discussed in this section.
} 
services. Section 27 not only allows a person to have access to health care but it also follows the international example of the ICESCR by stating that the government has a duty to steadily improve people's health care. Section $27(2)$ reads that: "the state must take reasonable legislative measures, within its available resources, to achieve the progressive realisation of each of these rights." Section 27 imposes both positive and negative obligations on the state. The positive obligation pertaining to section $27(1)$ is discussed above. Section $27(3)$, however, imposes a negative obligation on the state by stipulating that no person may be refused emergency care. As with all other rights in the Bill of Rights, the state's general positive duties regarding these rights are set out in section $7(2)$ of the Constitution. The state is required to respect, protect, promote and fulfil the right to health. Section 27 is not an absolute right and is subject to the limitation clause.

It should be borne in mind, however, that section 27 is not the only constitutional provision dealing with a right concerning health. As discussed earlier in this chapter the right to bodily and psychological integrity also directly protects a person's health. Furthermore, the health of children and prisoners is also directly protected by section $28(1)(c)^{164}$ and section $35(2)(e)^{165}$ of the Constitution respectively. There are additional rights that have an indirect bearing on the right of health, such as the rights to life, human dignity, equality and housing. ${ }^{166}$

As a socio-economic right, the right to healthcare poses a challenge to the courts in that the development of socio-economic rights jurisprudence in South Africa is still in its infancy. ${ }^{167}$ The Constitutional Court has affirmed, though, that socio-economic rights are justiciable and that the principle of the separation of powers does not have the effect of depriving courts of competence over such rights. ${ }^{168}$ There have

\footnotetext{
164 Section 28(1)(c) of the Constitution reads that: "Every child has the right to basic nutrition, shelter, basic health care services and social services".

165 Section $35(2)(e)$ of the Constitution reads that: "everyone who is detained, including every sentenced prisoner, has the right to conditions of detention that are consistent with human dignity, including at least exercise and the provision, at state expense, of adequate accommodation, nutrition, reading material and medical treatment".

166 Ngwena and Cook "Rights Concerning Health" 130.

167 Ngwena 2000 Med Law Int 2.

168 Ngwena and Cook "Rights Concerning Health" 132.
} 
been four Constitutional Court decisions that have a direct impact on the development and the understanding of the right to health care. In this section I will briefly discuss only three of these cases and the direct influence they have had on the right to health. ${ }^{169}$ The relevance of these cases pertaining to kidney transplants will be discussed later in this article.

The first and most important case to be discussed in this section is Soobramoney $v$ Minister of Health, KwaZulu Natal. Soobramoney, a 41-year-old unemployed man, was a diabetic who suffered from ischaemic heart disease and cerebro-vascular diseases which caused him to have a stroke in 1996. In that same year his kidneys also failed. His condition was regarded as irreversible and by the time of the court case he was in the final stages of renal failure. His life could have been prolonged by means of renal dialysis, but due to the limitations of the facilities available at the Addington state hospital dialysis was denied. ${ }^{170} \mathrm{His}$ request was denied also because he did not meet the medical criteria for providing dialysis at state expense. ${ }^{171}$ It should be noted that prior to the application Soobramoney had been receiving dialysis via private care, but his funds had run out, which is why he sought dialysis from a state hospital.

Soobramoney then decided to make an urgent application to the High Court for an order directing the Addington hospital to provide him with renal dialysis and interdicting the respondent from refusing him admission to the renal unit of the hospital. In his application he relied on section $27(3)$ and 11 of the Constitution. ${ }^{172}$ The application was dismissed and Soobramoney appealed to the Constitutional Court. The Court was of view that the right to life argument was inappropriate in this

169 The fourth case Van Biljon v Minister of Correctional Services 19974 SA 441 (C) will be omitted as it has limited value as a precedent and does not contribute to my argument.

170 Soobramoney sought renal dialysis therapy from the Addington state hospital in Durban. The hospital provided treatment to only a limited number of patients due to the fact that their renal unit had only 20 dialysis machines. Some of the machines were already in a poor condition. The hospital further noted that each treatment takes four hours and a further two hours for the cleaning of the machine before it could be used again.

171 Renal dialysis could be provided only to patients who were candidates for renal transplantation. Thus dialysis was provided only to patients who needed it as short-term therapy. As Mr Soobramoney was suffering from other diseases he was not a fit candidate for transplantation. Section 11 of the Constitution was discussed earlier in section 3 of this article. 
case as the Constitution provided explicitly for the right to health. ${ }^{173}$ Regarding section 27(3) the Court was of the view that "emergency medical treatment" was capable of a broader meaning to include ongoing treatment for chronic conditions, but it was not so broad to include conditions such as chronic renal failure, but rather for sudden catastrophe or unexpected trauma. ${ }^{174}$ Soobramoney's condition was described as an ongoing state of affairs and not an emergency which required immediate remedial treatment. ${ }^{175}$ The Court decided that section 27(3) did not apply to the facts of this case. The Court also emphasised that even if chronic renal failure could be regarded as an emergency, the state was not violating its obligation as its resources were scarce. If section 27(3) were to have been interpreted in favour of Soobramoney, the state's obligation to ensure access to health care services would have been severely jeopardised. The state would have been constantly forced to provide immediate access to health care services wherever and whenever it was demanded. ${ }^{176}$ Although the state has a constitutional duty to comply with the obligations imposed on it by section 27 of the Constitution it was held in Soobramoney that the state did not breach its constitutional obligation by refusing Soobramoney renal dialysis.

The second case pertaining to the enforcement of socio-economic rights concerning health is Minister of Health $v$ Treatment Action Campaign ${ }^{177}$. This case was an appeal by the government against the decision of the High Court. The applicants had challenged the decision of the government to confine the dispensation of Nevirapine to 18 pilot sites for the purpose of the prevention of the mother-to-child transmission of HIV. The main argument of the applicants was that the government's failure to provide access to all anti-retroviral therapy to prevent the

173 "In our Constitution the right to medical treatment does not have to be inferred from the nature of the state established by the Constitution or from the right to life which it guarantees. It is dealt with directly in section 27" (Soobramoney v Minister of Health, KwaZulu Natal 199712 BCLR 1696 (CC) para 19).

174 The purpose of the right seems to be to ensure that treatment is given in an emergency, and is not frustrated by reason of bureaucratic requirements or other formalities. What the section requires is that remedial treatment that is necessary and available be given immediately to avert harm (Soobramoney v Minister of Health KwaZulu Natal 199712 BCLR 1696 (CC) para 20).

175 Soobramoney $v$ Minister of Health KwaZulu Natal 199712 BCLR 1696 (CC) para 21.

176 Berger "Constitution and Public Health Policy" 36.

177 Minister of Health v Treatment Action Campaign 200210 BCLR 1033 (CC) - hereafter referred to as the TAC-case. 
mother-to-child transmission constituted a number of breaches of the provisions of the Constitution. The provisions that were being breached were section 7(2), 10, 12(2)(a), 27, 28(1)(c), $195^{178}$ and 237. ${ }^{179}$ The applicants had been successful before the High Court, but the case had focused especially on the interpretation and application of section 27(1) and (2) of the Constitution. Botha J stated that the government had not taken reasonable measures to realise the right of access to health care. The judge had granted an order to make Nevirapine available to all pregnant women who gave birth in the public sector and to their babies if a doctor was of the opinion that the Nevirapine is needed. The government appealed to the Constitutional Court against the decision. The Constitutional Court upheld the decision of the High Court and the appeal was determined by the application of section 27. In the TAC-case it was stated of rights such as access to education, land, housing, health care, food and water: ${ }^{180}$

These are the socio-economic rights entrenched in the Constitution, and the state is obliged to take reasonable legislative and other measures within its available resources to achieve the progressive realisation of each of them. In the light of our history this is an extraordinarily difficult task. Nonetheless it is an obligation imposed on the state by the Constitution.

In this case it was held that the decision to confine Nevirapine to only 18 pilot sites was unreasonable and thus constituted a breach of the state's obligations under sections 27(1) and (2) to the extent that it was rigid and inflexible. ${ }^{181}$ The mothers and their new-born babies outside the pilot sites were being denied a potentially lifesaving drug that could be administered within the available resources of the state. The judgement of this case illustrates that the Constitutional Court regards the state as a servant of the Constitution and that the state will be held to the duty to perform its constitutional duties. ${ }^{182}$

178 Section 195 of the Constitution requires that public administration must be governed by democratic values enshrined in the Constitution and that a high standard of professional ethics must be promoted and maintained.

179 Section 237 of the Constitution stipulates that all constitutional obligations must be performed diligently and without delay.

180 TAC-case para 94.

181 TAC-case para 80.

182 Swanepoel Embryonic Stem Cell Research and Cloning 154. 
The relevance of the last constitutional case of importance o this contribution, Khosa $v$ Minisiter of Social Development; Mahlaule v Minister of Social Development ${ }^{183}$ lies in section 27(2) of the Constitution. The decision here deals with the costs of extending social security to all. This case considered the reasonableness of the statutory limitation on access to an existing social assistance programme, and how this affects the state's positive obligation set out in section 27(2) of the Constitution. The Court rejected the state's allegation that the extension of the benefits in question to all eligible permanent residents would impose an extensive financial burden on the state. ${ }^{184}$ In doing so the Court emphasised that the state had failed to provide clear evidence to show what the additional cost of providing social grants to aged and disabled residents would be. ${ }^{185}$ It can be deduced from this case that the state cannot simply plead poverty when it comes to realising a socio-economic right. Instead it has to make out a case that it is indeed limited by resources. ${ }^{186}$

If a certain resource has been limited for a number of years, is the state not under an obligation to provide an alternative that could relieve the need for it?

\subsection{The right to health and kidney transplants}

In 1946 the WHO proclaimed that the highest attainable state of health is an objective to aspire to. It is all too evident that this objective has not been met in South Africa and will not be met in the near future. With the support of the relevant case law I should like to ask if the state is fulfilling its obligation in relation with the right to health. Thus, does the state really attempt to take reasonable legislative and other measures within its available resources to achieve the progressive realisation of health in the context of the availability of donor kidneys for transplant purposes? The author also asks if the state could not be expected to do more to provide an alternative, which where they lack the available resources to make more donor kidneys available would be to permit the remuneration of kidney donors.

\footnotetext{
183 Khosa v Minister of Social Development; Mahlaule v Minister of Social Development 20046 SA 505 (CC), hereafter referred to as the Khosa and Mahlaule cases.

184 Khosa and Mahlaule cases para 60.

185 Berger "Constitution and Public Health Policy" 44.

186 Berger "Constitution and Public Health Policy" 45.
} 
Firstly I would like to focus on the general obligations imposed on the state by section 7(2) of the Constitution. This section requires the state to respect, protect, promote and fulfil the right to health. Each of these obligations can be analysed individually. To respect means that the government must respect the right of access to health care services by not unfairly or unreasonably preventing people from accessing health care services. ${ }^{187}$ In a way, it could be argued that if the state does not grant persons the option of receiving remuneration for their kidney donations, the state is unreasonably erecting a barrier against kidney recipients' gaining access to available donor kidneys, and therefore to health care services. To promote entails that the state must create a legal framework so that individuals are able to realise their rights on their own. ${ }^{188}$ This obligation has a direct relevance to the remuneration of kidney donors. It could be argued that the state could create a legal framework that allows for the remuneration of a kidney donor, and thus individuals would be able to realise their right to health on their own. The obligation to fulfil entails that the government must create necessary conditions for people to access health care, by providing positive assistance, benefits and actual health care services. ${ }^{189}$ Once again the remuneration argument is of relevance to the obligation to fulfil. By allowing kidney donors to be remunerated the state is creating the necessary conditions for kidney recipients to access health care.

Secondly I should like to focus on the case law discussed above and how it contributes to the argument in favour of remuneration for kidney donors. Even though the Court arrived at the correct conclusion in Soobramoney with relevance to the facts of this specific case, there were nonetheless a number of shortcomings. This case was about renal dialysis and therefore had relevance to kidney transplantations and the state's available resources. The Court held that the right to life argument was inappropriate to this case. Yet the right to health and life should be seen as interconnected, because without the right to life no other rights are able to exist. By adopting this approach the Court unduly minimised the relevance of the

\footnotetext{
187 Berger "Constitution and Public Health Policy" 33.

188 Berger "Constitution and Public Health Policy" 33.

189 Berger "Constitution and Public Health Policy" 34.
} 
right to life. ${ }^{190}$ The Court also seemed to suggest that it had a limited role to play regarding decisions on the allocation of health care resources and the protection of socio-economic rights. ${ }^{191}$ The Court suggested that once it is asserted by a provincial or national health care provider that resources are unavailable, then that per se limits the realisation of the right of access to the service sought. ${ }^{192}$ It can be deduced from this that there is no promise in the judgement that the Court would actually ascertain whether the state and the provinces were in fact attempting the realisation of rights by making resources available that ought to be available, and utilising such resources effectively. ${ }^{193}$ In the Soobramoney case it was held that the state did not have to provide access to renal dialysis for people with Soobramoney's medical condition. I should like to contest this opinion. What would the judgement of this case have been if the facts were somewhat different? What if Soobramoney had been a patient who was an eligible candidate for a kidney transplant? Surely the Court would then have granted him access to renal dialysis and as soon as a viable kidney came available access to a kidney transplant. According to the proper reading of this case, the state cannot spend vast amount of money on non-priority areas if the affect is to limit access to essential services. ${ }^{194}$ If kidney donors are remunerated this would have quite the opposite effect. In the first place the state would not have to spend vast amounts because the amount they would be paying for a kidney transplant would be less than the cost of renal dialysis. ${ }^{195}$ The state would actually save money. Secondly, renal failure cannot be regarded as a non-priority area in South Africa, seeing that the major health problems are regarded as being AIDS, tuberculosis, malaria, gastroenteritis and hypertension. ${ }^{196}$ It should be noted that hypertension leads to renal failure and affects about $20 \%$ of the adult population. ${ }^{197}$ Thirdly, if the state were to spend funds on the remuneration of kidney donor

\footnotetext{
190 Ngwena and Cook "Rights Concerning Health" 136.

191 Moellendorf 1998 SAJHR 328.

192 Moellendorf 1998 SAJHR 330.

193 Ngwena and Cook "Rights Concerning Health" 137.

194 Berger "Constitution and Public Health Policy" 37.

195 The cost of a kidney transplantation, R250 000, includes the cost of the ImmunoPro Rx medication that must be taken in the first three months. After the procedure the cost of a kidney transplant is approximately R100 00 per annum, as opposed to the cost of renal dialysis, which is R200 000 per annum. Information supplied by Prof RS Britz on 29 April 2012 (rsbritz@gmail.com).

196 Naicker 2003 Kidney International 119.

197 Naicker 2003 Kidney International 119.
} 
patients this would not limit access to essential services (in this case, renal dialysis). Instead it would lighten the burden on the renal dialysis machines, and more patients would therefore have access to this life-prolonging treatment while they wait for a viable kidney match. Another point I should like to raise is that the case was heard 15 years ago, in 1997. Surely after such a length of time circumstances must have changed? At the time when this case was heard the state could meet only $30 \%$ of the demand for renal dialysis. ${ }^{198}$ Is this still the position today? Chaskalson $\mathrm{P}$ noted that: ${ }^{199}$

The state has to manage its limited resources in order to address all these claims. There will be times when this requires it to adopt a holistic approach to the larger needs of society rather than to focus on the specific needs of a particular individual within society.

If the Constitution allows the remuneration of kidney donors, then the state will be attending to the larger needs of society, seeing that there is a dire need for viable donor kidneys in South Africa.

The approach of the Court in the TAC-case clearly illustrates that the idea of the minimum core should be seen as integral to rather than independent from the question of whether or not the state has taken reasonable legislative and other measures to discharge its duty. ${ }^{200} \mathrm{Ngwena}$ and Cook are of the opinion that: ${ }^{201}$

Treatment Action Campaign itself is an instance where the state lost sight of its obligation concerning protecting health and the notion of providing a minimum floor or protection that was easily within its reach.

It could be asked if the state has not also lost sight of its obligations concerning the right to health of patients with end-stage renal failure. The demand for kidneys exceeds the supply extensively. There are not enough renal dialysis machines to keep patients alive whilst they await a viable kidney, neither are there enough viable kidneys available to relieve the stress of the dialysis treatment. It could be argued

\footnotetext{
198 Soobramoney-case para 26.

199 Soobramoney-case para 31.

200 Ngwena and Cook "Rights Concerning Health" 143.

201 Ngwena and Cook "Rights Concerning Health" 143.
} 
that kidney patients, like the mothers and children in the TAC case, also have a right to their life-saving treatment. "A floor of minimum protection," as said above, is easily within the state's reach concerning kidney recipients. If the remuneration of kidney donors were to be allowed, more kidneys would be available and there would not be a lack of available resources.

As averred in the Khosa and Mahlaule cases, the state cannot merely plead poverty. It has to make out a case that it is indeed limited by resources. If remuneration were to be allowed the state would not be limited by the resources available to it in the first place because enough kidneys would be available to meet the demand for transplants, and secondly because the funds presently available for dialysis could instead be used for transplants.

Consequently it is my opinion that the state is not fulfilling its obligation in sections $7(2)$ and $27(2)$ of the Constitution. The state is not respecting, promoting, protecting or fulfilling the kidney recipients' right to healthcare. Furthermore the state is not taking reasonable, legislative and other measures within its available resources to achieve the progressive realisation of the right to health pertaining to those in need of kidney transplants. The dire lack of available kidneys has been a problem for a number of decades, and the state should therefore provide the kidney recipients with an alternative option. They should be allowed to obtain a kidney in a constitutionally acceptable manner by having the state remunerate the kidney donor.

\section{Conclusion}

This article has sought to examine if the remuneration of kidney donors could be regarded as constitutionally acceptable. In my opinion all of the constitutional rights that have been examined have proved that they could be used in favour of the remuneration of kidney donors.

The right to life is regarded as the most important right of all the fundamental human rights because it is the foundation of all other rights. Without life no other 
right can exist. It was held in Makwanyane that the right to life implied that it had to be a life worth living. I have argued that the pain and suffering that accompany renal dialysis are such that the life of the patients is not a life worth living, but that a kidney transplant would give the patients a better life. The right to human dignity is regarded as interconnected with the right to life. According to Ackermann $\mathrm{J}$ the right to life incorporates the right to dignity. Human dignity and renal dialysis cannot coexist. It is also argued that the worldwide argument that a kidney donor's human dignity would be infringed if he received remuneration for his kidney donation is illogical. Furthermore the issue was also raised why the cruel and inhuman treatment of a criminal could be regarded as constitutionally unacceptable but the same treatment is regarded as constitutionally acceptable regarding an end-stage renal-failure patient. All persons are allowed to make decisions regarding their own bodies, as is guaranteed by the right to self-determination expressed in the Constitution. Thus, if a person is not allowed the option to decide whether or not he would like to be remunerated for his kidney donation, his right to self-determination is infringed. The remuneration of a kidney donor would have absolutely no effect whatsoever on the kidney donor's right to privacy. The donor would still be allowed to remain anonymous. Lastly, due to everyone's right to health care provided within the state's available resources, the state should allow persons to be remunerated for their kidney donation. Consequently, more end-stage renal-failure patients would have access to renal dialysis until a viable kidney became available, and it would always be possible for the state to provide kidneys within its available resources for the purpose of transplant operations.

If the state does not allow the remuneration of a kidney donor but merely leaves matters as they are at the moment, meaning that kidney donation is the only acceptable way to obtain a kidney, it could be argued that the state is infringing upon the rights to which a person is entitled by virtue of the Constitution.

Consequently, after careful consideration of the above it should be thought to be constitutionally acceptable to remunerate a kidney donor for his kidney. The sales of human kidneys are currently legally prohibited. I am strongly of the opinion that the 
legislation of kidney sales in a constitutionally acceptable manner would improve the current shortage of donor kidneys in South Africa. Furthermore, this would give hope to the thousands of South African patients who are presently waiting on a miracle. It would be reprehensible if the shortfall of legislative development is the only reason why South Africa is suffering from such an acute shortage of donor kidneys. 


\section{Bibliography}

Berger "Constitution and Public Health Policy"

Berger J "The Constitution and Public Health Policy" in Hassim A, Heywood M and Berger J (eds) Health and Democracy: A Guide to Human Rights, Health Law and Policy in Post-apartheid South Africa (Siber Ink Cape Town 2007) 3069

Botha 2009 Stell L Rev

Botha H "Human Dignity in a Comparative Perspective" 2009 Stell L Rev 171220

Carsten and Pearmain Foundational Principles

Carstens PA and Pearmain DL Foundational Principles of South African Medical Law (LexisNexis Butterworths 2007)

Currie and De Waal Bill of Rights Handbook

Currie I and De Waal J The Bill of Rights Handbook $5^{\text {th }}$ ed (Juta Cape Town 2008)

Danwood 2002 Human Rights Brief

Danwood MC "Toward Revitalizing Economic, Social, and Cultural Rights in Africa: Social and Economic Rights Action Centre and the Center for Economic and Social Rights v Nigeria" 2002 Human Rights Brief(10)17-32

Devenish Commentary

Devenish GE A Commentary on the South African Bill of Rights (Butterworths Durban 1999)

Dhai and McQuoid-Mason Bioethics

Dhai A and McQuoid-Mason D Bioethics, Human Rights and Health Law (Juta Cape Town 2011) 
Dugard International Law

Dugard J International Law: A South African Perspective $3^{\text {rd }}$ ed (Juta Cape Town 2006)

Formica et a/2010 Clin J Am Soc Nephro

Formica RN et al "Kidney Transplantation and HIV: Does Recipient Privacy Outweigh the Donor's Right to Information?" 2010 Clin J Am Soc Nephro 924928

Gill and Sade 2002 Kennedy Inst Ethics J

Gill MB and Sade RM "Paying for Kidneys: The Case Against Prohibition" 2002 Kennedy Inst Ethics J(12)17-45

Goolam 2001 PEL

Goolam NMI "Human Dignity - Our Supreme Constitutional Value" 2001 PEL (4)1-16

Hakim Introduction to Organ Transplantation

Hakim NS Introduction to Organ Transplantation (Imperial College Press London 1997)

Harillall and Kasiram 2011 Health SA Gesondheid

Harillall B and Kasiram M "Exploring the Bio-psychosocial Effect of Renal Replacement Therapy amongst Patients in a State Hospital in South Africa" 2011 Health SA Gesondheid (16)1-10

Heywood "Background to Health Law"

Heywood M "A Background to Health Law and Human Rights in South Africa" in Hassim A, Heywood M and Berger J (eds) Health and Democracy: A Guide to Human Rights, Health Law and Policy in Post-apartheid South Africa (Siber Ink Cape Town 2007) 2-29 
Jordaan South African Consumer's Information Privacy

Jordaan Y South African Consumer's Information Privacy (LLD-thesis UP 2003)

Killander "African Human Rights Law"

Killander M "African Human Rights Law in Theory and Practice" in Joseph S and McBeth A (eds) Research Handbook on International Human Rights Law (Cheltenham United Kingdom 2010) 388-413

Liebenberg 2005 SAJHR

Liebenberg $S$ "The Value of Human Dignity in Interpreting Socio-economic rights" 2005 SAJHR 1-33

Manby "Civil and Political Rights"

Manby B "Civil and Political Rights in the African Charter in Human and Peoples' Rights Articles 1-7" in Evans M and Murray R The African Charter on Human and Peoples' Rights: The System in Practice 1986-2006 $2^{\text {nd }}$ ed (Cambridge University Press Cambridge 2008) 171-213

Matas 2006 Clin J Am Soc Nephro

Matas AJ "Why we should Develop a Regulated System of Kidney Sales: A Call for Action!" 2006 Clin J Am Soc Nephro 1129-1132

Moellendorf 1998 SAJHR

Moellendorf D "Reasoning about Resources: Soobramoney and the Future of Economic Right Claims" 1998 SAJHR 327-333

Naicker 2003 Kidney International

Naicker S "End-stage Renal Disease in Sub-Saharan and South Africa" 2003 Kidney International 119-122 
Neethling et al Law of Personality

Neethling et al Neetling's Law of Personality (LexisNexis Butterworths Durban 1996)

Ngwena 2000 Med Law Int

Ngwena C "Substantive Equality in South Africa Health Care: The Limits of the Law" 2000 Med Law Int (4)1-21

Ngwena and Cook "Rights Concerning Health"

Ngwena C and Cook R "Rights Concerning Health" in Brand D and Heyns C (eds) Socio-economic Rights in South Africa (Pretoria University Law Press Pretoria 2005) 107-151

Rehof "Article 3"

Rehof L "Article 3" in Gudmundur A and Eide A The Universal Declaration of Human Rights: A Commentary (Scandinavian University Press 1992) 73-85

Rehman International Human Rights

Rehman J International Human Rights: A Practical Approach (Longman London 2003)

SALC Assisted Decision-making

South African Law Commission Assisted Decision-making: Adults with Impaired Decision-making Capacity - Discussion Paper 105, Project 122 (SALC Pretoria 2004)

Schicktanz, Wiesermann and Wöhlke Organ Transplantation

Schicktanz S, Wiesermann C and Wöhlke S Teaching Ethics in Organ Transplantation and Tissue Donation (Univeritätverlag Göttingen 2010) 
Schmidt Justice at Nuremberg

Schmidt U Justice at Nuremberg: Leo Alexander and the Nazi Doctors' Trail (Palgrave MacMillan Hampshire 2006)

Slabbert 2010 PEL

Slabbert M "Ethics, Justice and the Sale of Kidneys for Transplantation Purposes" 2010 PELJ 77-105

Swanepoel Embryonic Stem Cell Research and Cloning

Swanepoel M Embryonic Stem Cell Research and Cloning: A Proposed Legislative Framework in the Context of Legal Status and Personhood (LLMthesis UP 2006)

\section{Register of cases}

Carmichele v Minister of Safety and Security 20014 SA 398 (CC)

Christian Lawyers Association of South Africa v Minister of Health 19984 SA 1113

Dawood v Minister of Home Affairs 20003 SA 936 (CC)

Du Plessis v De Klerk 19963 SA 850 (CC)

Ex parte Minister of Safety and Security: In re S v Walters 20024 SA 613 (CC)

Ferreira v Levin 19961 SA 984 (CC)

Investigating Directorate: Serious Economic Offences v Hyundai Motor Distributors

(Pty) Ltd: In re Hyundai Motor Distributors (Pty) Ltd v Smit 20011 SA 545 (CC)

Katangese People's Congress v Zaire Communication 75/92

Khosa v Minister of Social Development; Mahlaule v Minister of Social Development 20046 SA 505 (CC)

Minister of Health v Treatment Action Campaign 200210 BCLR 1033 (CC)

Phillips v De Klerk 1983 TPD (unreported)

Social and Economic Rights Action Center and the Center for Economic and Social Rights v Nigeria Communication 155/96 
Soobramoney v Minister of Health (KwaZulu Natal) 19981 SA 765 (CC)

S v Makwanyane 19953 SA 391 (CC)

Van Biljon v Minister of Correctional Services 19974 SA 441 (C)

\section{Register of legislation}

Choice on Termination of Pregnancy Act 92 of 1996

Constitution of the Republic of South Africa, 1996

National Health Act 61 of 2003

Promotion of Access to Information Act 2 of 2000

\section{Register of international and regional legal instruments}

African Charter of Human and People's Rights (1981)

International Covenant on Civil and Political Rights (1966)

International Covenant on Economic, Social and Cultural Rights (1966)

Universal Declaration of Human Responsibilities (1997)

Universal Declaration of Human Rights (1948)

Vienna Convention on the Law of Treaties (1969)

\section{Register of internet sources}

Canadian Institute for Health 2010 http://bit.ly/YOQNrz

Canadian Institute for Health 2010 Renal Transplantation Saving Millions on Dialysis Costs http://bit.ly/YOQNrz [date of use 20 May 2012]

Clark 2006 http://bit.ly/WWupRe

Clark PA 2006 Financial Incentives for Cadaveric Organ Donation: An Ethical Analysis http://bit.ly/WWupRe [date of use 23 May 2012] 
Davison and Rosielle $2008 \mathrm{http} / / /$ bit.ly/ZOZaSX

Davison SN and Rosielle DA 2008 Withdrawl (sic) of Dialysis: Decision Making http://bit.ly/ZOZaSX [date of use 21 May 2012]

De Klerk 2011 http://bit.ly/14dSC8b

De Klerk A 2011 A Simple Answer to Kidney Diseases http://bit.ly/14dSC8b [date of use 19 Apr 2012]

Hartwell 2010 http://bit.ly/149gfyc

Hartwell L 2010 Global Organ Donation Policies around the World http://bit.ly/149gfyc [date of use 18 Aug 2011]

Joseph 2011 http://bit.ly/ZoHrl2

Joseph R 2011 The Right to Life is the Most Important of All http://bit.ly/ZoHrl2 [date of use 26 March 2013]

KHA 2008 http://bit.ly/ZzEJfQ

Kidney Health Australia 2008 Kidney Facts http://bit.ly/ZzEJfQ [date of use 25 Apr 2011]

McLean 2012 http://bit.ly/XrIpxs

McLean SAM 2012 Human Rights and Bioethics http://bit.ly/XrIpxs [date of use 17 May 2012]

Minister of Health 2008 http://bit.ly/YqsHG5

Minister of Health Singapore 2008 Human Organ Transplant Act (HOTA) http://bit.ly/YqsHG5 [date of use 29 May 2012]

National Kidney Foundation 2009 http://bit.ly/Y14Ptd National Kidney Foundation 2009 When Stopping Dialysis Treatment is your Choice http://bit.ly/Y14Ptd [date of use 21 May 2012] 
Newman 2010 http://bit.ly/YHND7y

Newman B 2010 The Doctors of the Holocaust http://bit.ly/YHND7y [date of use 17 May 2012]

Organ Donor Foundation 2012 http://bit.ly/YqtVB8

Organ Donor Foundation 2012 Home Page http://bit.ly/YqtVB8 [date of use 5 May 2011]

UN CESCR 2000 http://bit.ly/102nBOG

United Nations Committee on Economic, Social and Cultural Rights 2000 General Comment 14: The Right to Highest Attainable Standard of Health http://bit.ly/102nBOG [date of use 19 Apr 2012]

UN Human Rights Committee 1988 http://bit.ly/ZfoHEn

United Nations Human Rights Committee 1988 General Comment 16: The Right to Respect of Privacy, Family, Home and Correspondence and Protection of Honour and Reputation http://bit.ly/ZfoHEn [date of use 17 May 2011]

\section{List of abbreviations}

ACHPR

CESCR

Clin J Am Soc Nephro ICCPR

ICESCR

Kennedy Inst Ethics ]

$\mathrm{KHA}$

Med Law Int

PELJ

SAJHR

SALC
African Charter of Human and People's Rights Committee on Economic, Social and Cultural Rights Clinical Journal of the American Society of Nephrology International Covenant on Civil and Political Rights International Covenant on Economic, Social and Cultural Rights

Kennedy Institute of Ethics Journal

Kidney Health Australia

Medical Law International

Potchefstroom Electronic Law Journal

South African Journal on Human Rights

South African Law Commission 
Stell L Rev

UDHR

UN

WHO
Stellenbosch Law Review

Universal Declaration of Human Rights

United Nations

World Health Organisation 